\title{
Synthesis and Characterization of Nanoemulsion Andaliman Aroma Compound
}

\author{
Rienoviar $^{\mathrm{a}, *}$, Dwi Setyangingsih ${ }^{\mathrm{b}}$, Sudirman $^{\mathrm{c}}$, Fitriani Kasim $^{\mathrm{d}}$ \\ ${ }^{a}$ Centre for Agrobase Industry Jl. Ir, H Juanda No 11 Bogor, West Java, Indonesia \\ ${ }^{b}$ Departement of Agricultural Industrial Technology, Bogor Agricultural University, West Java, Indonesia \\ ${ }^{c}$ Science and Advanced Material Technology Center - National Nuclear Energy Agency, Center for Research in Science and Technology \\ Area, Serpong, South Tangerang, Indonesia \\ ${ }^{d}$ Department of Agricultural Industrial Technology, Andalas University, Limau Manis Padang, West Sumatera, Indonesia \\ Corresponding author: ${ }^{*}$ rienoviar@gmail.com
}

\begin{abstract}
Andaliman is widely used in culinary and medicine for a long time ago. However, it has a short storage life, so it takes a preservation process. The study aims to create the synthesis of the Andaliman aroma compound and its characterization. The synthesis process is conducted with several variables such as oleoresin concentration range of 10 and 20 wt\% and type of surfactants such as Tween 80, mixed of Tween 80:20 (50:50 wt\%) and Tween 20. The homogeneous Maltodextrin solution and gum Arabic solution, called solution 1 and 2, are created by using ultra turrax with a speed of $18,000 \mathrm{rpm}$ for 5 minutes. Then they are mixed with a comparative composition 2:3 as wall material. After that, the mixture is added by three different types of surfactants such as Tween 80, mixed Tween 80 and 20 (1:1), and Tween 20. Andaliman nanoemulsion is generated by mixing Andaliman oleoresin, wall materials, and water with two different compositions, such as 10:20:100 and 20:20:100 and also nine wt\% of surfactants. Their treatment mixing is similar to the manufacture of wall materials. The characterization of nano emulsification was conducted by analyzing droplet size, zeta potential, polydispersity index (PDI), emulsion stability index (ESI), and viscosity. The study results showed that mixed $20 \mathrm{wt} \%$ oleoresin concentration and emulsifier of Tween 20 produced $100 \%$ of ESI value with a particle size of $68.5 \mathrm{~nm}$ and zeta potential of $-44.95 \mathrm{in}$ which showed the stability of both emulsion and nanometer-sized particle.
\end{abstract}

Keywords-Andaliman; nanoemulsion; encapsulation; spray drying.

Manuscript received 6 Dec. 2019; revised 13 Dec. 2020; accepted 17 Mar. 2021. Date of publication 30 Jun. 2021. IJASEIT is licensed under a Creative Commons Attribution-Share Alike 4.0 International License.

\section{INTRODUCTION}

Andaliman is species that contain aroma compounds from the citrus family. It is widely used as a cooking spice and traditional medicine for the Batak tribe community [1]. However, it is quickly decayed or damaged due to its extracted compounds oleoresin, produced using the maceration process-mixed alcohol and ethyl acetate. It contained mostly compounds of geranyl acetate and limonene [2] in which sensitive to light, heat, and oxygen. Therefore, it is necessary to research the preservation process.

Oleoresin, the extracted compounds of Andaliman, showed a flavor profile that approaches the freshly ground spices to be accepted as a natural flavoring ingredient [3]. However, it is sensitive to light, heat, and oxygen, so that it has a short storage life. The preservation process was conducted using an oven blower by drying method to maintain its aroma [4].
Microencapsulation provides better stability while controlling the release of bioactive compounds [5].

Surfactants are essential during the synthesis process of nanometer-sized particles $(<100 \mathrm{~nm})$ to prevent the coagulation process because of the attractive force between particles [6], [7]. The manufacturing of nanoemulsion is influenced by the type of surfactant and emulsification energy [8]. There are two types of surfactants: Tween 80 and Tween 20 , which are used to create oleoresin-based encapsulation, especially for fennel oleoresin and turmeric; and astaxanthin oleoresin, respectively [9]-[11]. The emulsion is a colloid of two or more immiscible liquids where one liquid is dispersed as a small droplet (internal phase), and the other is a continuous phase (external phase). The stabilized emulsion is formed by adding an emulsifying agent [12]. One of them is gum Arabic. In this research, we studied several factors such as homogenous speed, the ratio of gum Arabic, maltodextrin, and concentration of wall materials on the manufacturing of 
emulsion. However, in the first step, we must know both the speed of the homogenizer and the optimized composition of mixed gum Arabic and maltodextrin to create a stabilized emulsion.

Both high and low energy methods can be used to prepare the nano-sized particles. In this research, high-speed ultra turrax was used to make nano-sized emulsions and form stable emulsions. The emulsification process of the material will affect the lipophilic and hydrophilic balance of the system [13].

In this study, we set numbers of homogenizer speed such as $16,000,18,000,20,000,22,000$, and $24,000 \mathrm{rpm}$ to get the optimized speed of the homogenizer to create a stabilized emulsion. In terms of the composition of oleoresin: water: emulsifier: wall materials (gum arabic: maltodextrin) is about 10:100:9:20 (1:1) respectively. The research purpose is to create Andaliman aroma compounds used as cooking spices and traditional medicine with a stronger and more stable aroma activity. So, it has a longer storage life.

\section{MATERIAL AND METHOD}

\section{A. Materials}

This research used several materials such as andaliman, maltodextrin with DE 10-15 made by Zucheng dong xiao Biotechnology Co. Ltd, China, gum arabic, Tween 20, and Tween 80 made by Merck. The analyzer instruments used are ultra turrax homogenizer branded Ika and type of T 25D particle size analyzer zeta sizer nano series branded Malvern.

\section{B. Procedure}

Nanoemulsion manufacturing was conducted by three steps as follows:

- Particle size reduction of emulsions with homogenizer speed treatment.

- Synthesis of nanoemulsion including (a) The effect of the ratio of gum arabic and maltodextrin on the preparation of nanoemulsions, (b) the effect of surfactant ratio and concentration of andaliman oleoresin.

- Characterization of Andaliman aroma compound nanoemulsion. In this study, statistical analysis was carried out before the experimental design in the making of the nanoemulsions process.

1) Particle size reduction of emulsions: In this process, we set much homogenizer speed such as 16,000, 18,000, 20,000, 22,000 , and $24,000 \mathrm{rpm}$ to get the optimized speed homogenizer to create a stabilized emulsion. The composition used is oleoresin: water: emulsifier: wall materials (gum arabic: maltodextrin) with a specified percentage of 10:100:9:20 (1:1), respectively.

2) Synthesis of Nano emulsion:

- Influence of ratio gum Arabic and maltodextrin on the preparation of nanoemulsion. Maltodextrin has various aspects of function, including film formation properties, the ability to reduce the interface tension yet it is not a good emulsifier [14], good flavor carriers and encapsulants because of bind taste and reduces the permeability of oxygen to the wall matrix, solubility, and a relatively low price. To protect the flavor compounds in the emulsion, gum Arabic is very suitable to be mixed with maltodextrin because gum arabic has good film-forming properties [15]. Gum arabic has two poles with different charges, hydrophobic and hydrophilic, because of its protein groups [16]. The modification of the Assadpour and Jafari Method was used as a method to produce andaliman nanoemulsion [17]. First of all, solution 1 was made by mixing maltodextrin with water through homogenous state using ultra turrax with the speed of $18,000 \mathrm{rpm}$ for 5 minutes. By using a similar method, solution 2, which consisted of gum arabic, has been made. Then the two solutions are mixed with a comparative composition $2: 3$ as wall material. After that, it is added by three different types of surfactants, such as Tween 80, mixed Tween 80 and 20 (1:1) and Tween 20.

- The effect of surfactant ratio and concentration of andaliman oleoresin. The effect of surfactant was conducted to obtain a stable nanoemulsion with the design analysis, which carried out using an experimental design.

- Statistical Analysis and Experimental Design. The experimental design was used in factorial, completely randomized patterns where factor $\mathrm{A}$ is oleoresin concentration, which consists of 2 levels $(\mathrm{A} 1=10$ and $A 2=20)$. Whereas factor $B$ is surfactant which consists of 3 levels $(\mathrm{B} 1=$ Tween $80, \mathrm{~B} 2=$ mixed Tween 80 and 20 (ratio 1:1), B3 = Tween 20). Andaliman nanoemulsion is made by mixing andaliman oleoresin, wall materials, and water with two different compositions, such as 10:20:100 and 20:20:100 and also $9 \mathrm{wt} \%$ of surfactants. Their mixing treatment is the same as the manufacture of wall materials. Several variables are analyzed, such as droplet size, zeta potential, polydispersity index (PDI), emulsion stabilization index, and viscosity. The most stable emulsion on nanoemulsion manufacturing continued for the manufacture of andaliman encapsulates using spray drying. The experimental design of nanoemulsion manufacturing was used in the form of factorial, completely randomized patterns with two replications. The diversity analysis was conducted using software SAS 9.4.

3) Characterization of Andaliman Aroma Compound Nanoemulsion:

- Droplet Size, Zeta Potential, and PDI (Poly Dispersity Index): The particle size of oleoresin was measured using Particle Size Analyzer (PSA) zeta sizer nano series made by Malvern in 2014. After turning on the analyzer, the temperature is set to $25^{\circ} \mathrm{C}$. Then the intensity is regulated in which a drop of sample is dissolved in $20 \mathrm{~mL}$ distilled water. Around $1 \mathrm{~mL}$ sample is added to cuvette and then measured. The data, such as droplet size, particle size distribution, and zeta potential, will be processed automatically on the computer.

- Emulsion Stability Index Test: First, $15 \mathrm{~mL}$ of the emulsion was added to a centrifuge tube, then closed 
and stored at room temperature 24 hours. The emulsion will be separated into three parts after storing: opaque on the top, haze on the middle, and transparent on the bottom. Especially the two latest mentioned parts; they called it a serum layer (HS) and total emulsion height (HE). Its thickness could be seen on the tube. The change of creaming was measured using a ruler and creaming index that has been calculated using Equation 1 .

Indeks creaming $(\mathrm{IC})=\left(\frac{\mathrm{HS}}{\mathrm{HE}}\right) \times 100 \quad \ldots \ldots \ldots \ldots$ (1)

- Viscosity: Viscosimeter followed the AOAC974.07 method, first action 1974. The formula is as follows.

Viscosity $(\mathrm{cP})=($ flow rate $\times$ molecular weight $\mathrm{x}$ flow rate $) \%$

\section{RESULTS AND DisCUSSION}

The emulsification process is very challenging due to coalescence is rarely happened after this process. On the initial agitation process, particle collisions occurred. In this step, the droplet stabilization depended on the speed and time of stirring, which can be attributed to the distribution of emulsifiers between phases. Slow interface film formation or disruption of film formation by continuous stirring contributes to emulsion stability.

\section{A. Particle Size Reduction of Emulsions with Homogenizer Speed Treatment}

Ultra turrax for emulsion particle size reduction is carried out to reduce the particle size on a micro-scale.

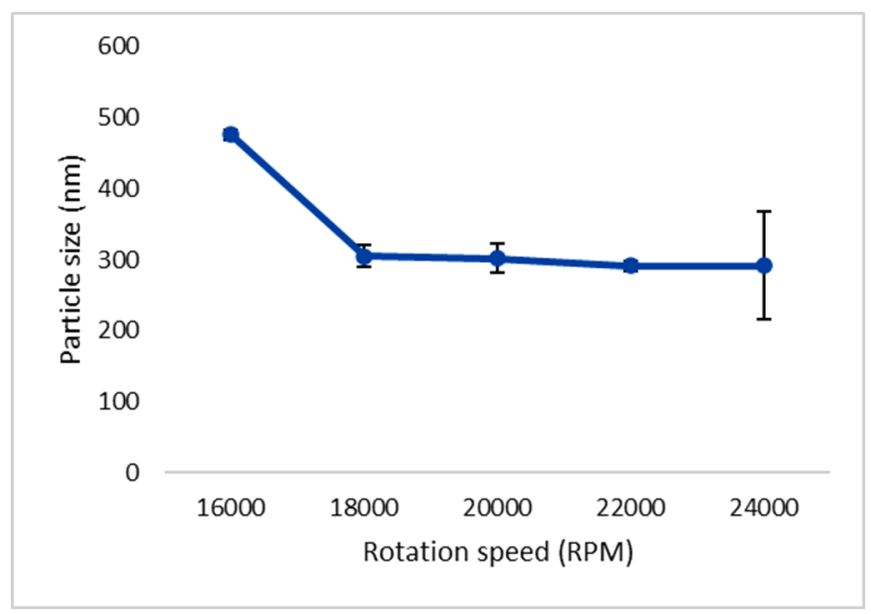

Fig. 1 Influence of homogenizer speed on particle size

As depicted in Figure 1, the particle size decreased with the increase of the homogenizer speed of ultra turrax. The homogenizer speed between 18,000 to $24,000 \mathrm{rpm}$ did not give significant results, yet different on between 16,000 rpm. According to Ralla T., the homogenizer is a suitable instrument to decrease the droplet size of liquid-liquid phase dispersion resulting in a stabilized emulsion [18], [19].

On the homogenizer speed range of 20,000-24,000 rpm, an extreme vibration occurred. While on the homogenizer speed of 22,000 and 24,000 rpm, it turned to be the dark green and brownish color with the charred smell, respectively.
As depicted in Figure 2, the cream phase that stirred on $18,000 \mathrm{rpm}$ of homogenizer speed is greater than that of stirred on 20,000,22,000, and 24,000 respectively.t happened due to excessive energy from high homogenizer speed. Then it turned the materials out to be brownish and created a charred smell. In short, we stated that heat energy increased with an increased rotation speed [20], [21].

The large particle sizes are formed at the high stirring rates in the systems where the surfactant is not suitable, thus facilitating the transport of molecular mass into larger lumps. However, the stable emulsion can be produced on the appropriate agitation speed and suitable surfactants as conducted by Moreira et al. [22]. The formation of stable beta-carotene nanoemulsion was obtained with a surfactant concentration of $7 \% \mathrm{wt}$, soy lecithin as a suitable surfactant, $10,000 \mathrm{rpm}$ of agitation speed, and 5-20 minutes of agitation time. It produced a particle size of $429 \mathrm{~nm}$.

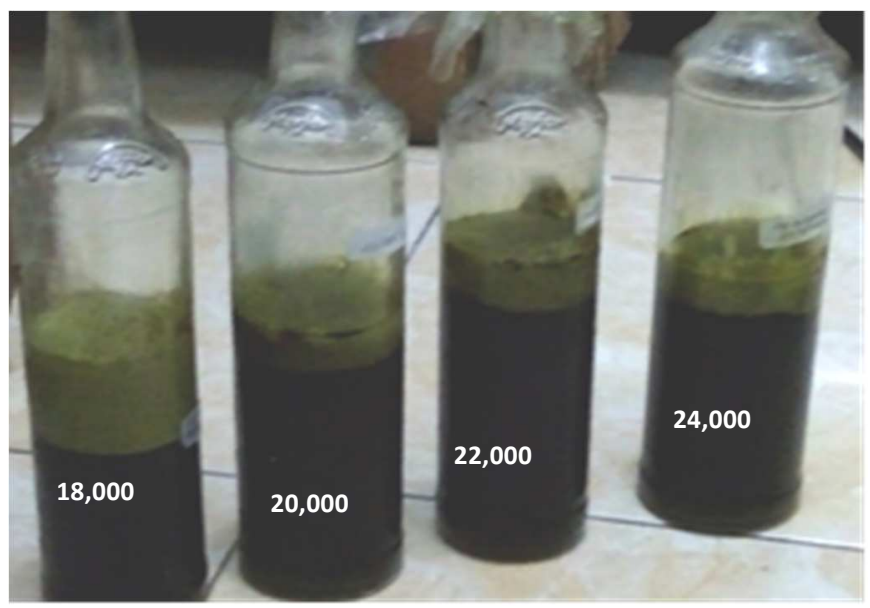

Fig. 2 Andaliman emulsion on homogenizer speed range of 18,000-24,000 rpm

The starch content on the emulsion turned to be brownish due to the caramelization process as a result of heat energy from rotation energy. It cannot be used. In brief, the suitable homogenizer speed on this research is $18,000 \mathrm{rpm}$. A previous study supported that the homogenizer speed of $18,000 \mathrm{rpm}$ produced stabilized emulsion on bioactive substance emulsion release system. It showed on Figure 2 [23], [24]. Agitation speed of 18,000 rpm and gum arabic: maltodextrin (3:2) ratio were continued to obtain a stable emulsion; the process conditions were carried out with variations in the types of surfactants Tween 80 and Tween 20 .

\section{B. Synthesis of Nanoemulsion}

1) The effect of the ratio gum arabic and maltodextrin on the preparation of nanoemulsions: Maltodextrin has various aspects of function, including film formation properties to reduce the interface tension, yet it is not a good emulsifier [14], good flavor carriers and encapsulants because of bind taste and reduces the permeability of oxygen to the wall matrix, high solubility and a relatively cheap price [25]. In order to protect the flavor compounds in the emulsion, gum arabic is very suitable to be mixed with maltodextrin because gum arabic has good film-forming properties [15]. Gum arabic has two poles with different charges, hydrophobic and hydrophilic, because of its protein groups. 
2) The ratio of wall materials composed of gum arabic and maltodextrin affects the particle size. It can protect the encapsulated active compound. Gum arabic acts as surfaceactive agents and matrix dryers to prevent the loss of volatile compounds. According to Tsai FH. et al., gum arabic can form a good film layer to protect the core material coated [5], [26]. Meanwhile, maltodextrin has a simple molecular structure to easily develop the encapsulation to give the efficiency of protection or controlled release. It can effectively protect from oxygen, water, and light because wall materials can avoid contact with other substances. The ratio of gum arabic and maltodextrin could be seen as following Figure 3.

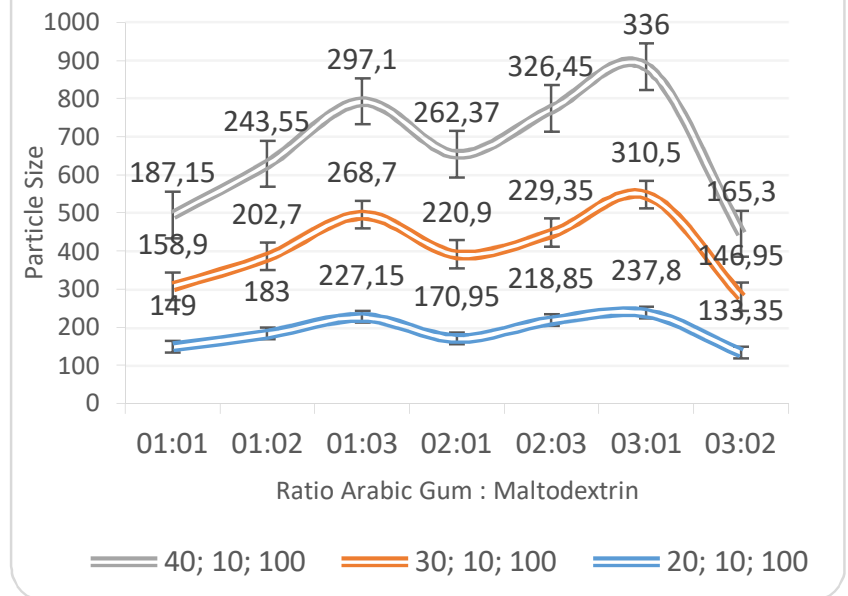

Fig. 3 Influence of ratio gum arabic and maltodextrin on emulsion particle.

Based on the analysis of variance results, it is known that both treatment ratio and concentration of wall materials are different from other treatments except ratio gum arabic and maltodextrin of $2: 3$ and $1: 3$. At the same time, the concentration of wall materials of $20 \mathrm{wt} \%$ is different from 30 $\mathrm{wt} \%$ or even $40 \mathrm{wt} \%$. We could take brief information from Figure 3 that the particle size increased with the increasing of wall materials concentration on the same emulsifier concentration. It happened due to the reassembly of particles. But at a ratio of 3:2, the particle size shrunk again so that this ratio is suitable for the good capsule to avoid reagglomeration. As research by Hermanto, the ratio of gum arabic and maltodextrin $(3: 2)$ produced stabilized emulsion [27].

Assadipour and Jafari [17] stated that if the concentration of gum arabic is higher than maltodextrin, it could produce stabilized emulsion because the excessive both hydrophobic and hydrophilic poles will bridge the emulsion formation process. According to Mariod et al. [28], the formation of gum's emulsifying properties is determined by the protein aggregate content of the protein-peptide distribution between parts with variations in their molecular weight and the availability of protein-peptide molecules for absorption. The $3 \%$ protein content provides a good quality of gum arabic. The process of absorption of gum Arabic and essential oil in an emulsion is depicted in figure 4.
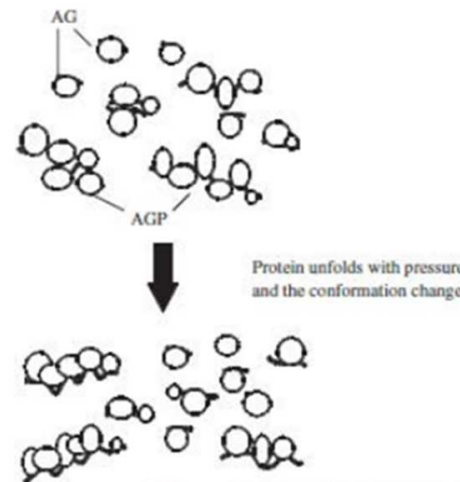

Hydrophobic p

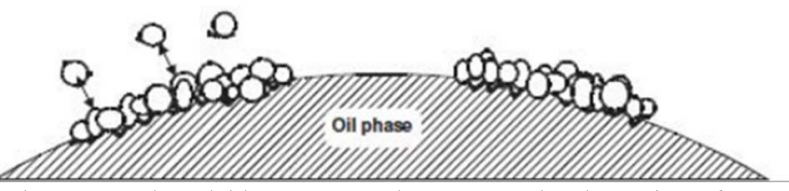

Fig. 4 The proposed model by AOKI et al., 2017, on the absorption of gum arabic against oil droplets.

\section{Characterization of Andaliman Aroma Compound Nanoemulsion}

1) Droplet Size: The emulsion particle size showed stability of emulsion according to 6 Emulsion particles below $100 \mathrm{~nm}$ are more stable than particles above $100 \mathrm{~nm}$.

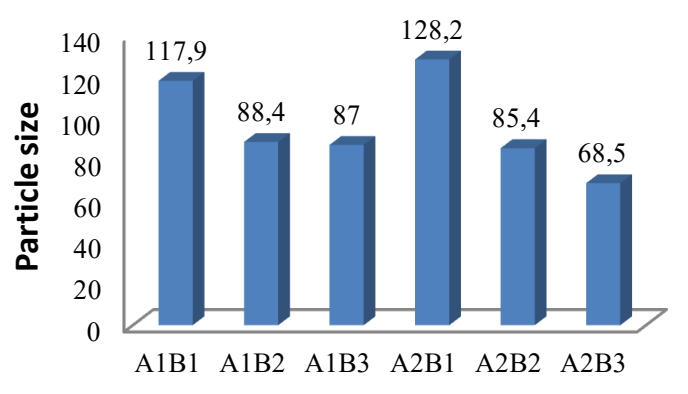

Where:

Fig. 5 The size of andaliman nanoemulsion particles

A1: Concentration Oleoresin 10\% A2: Concentration Oleoresin 20\%

B1: Tween $80 \quad$ B2: Tween 20:Tween $80=1: 1$

B3:Tween 20\%

Figure 5 showed that the kind of surfactant influenced particle size. Especially for surfactant Tween 80, we have $117.9 \mathrm{~nm}$ of A1B1, 25,1 nm of A2B1. All treatments are close to 100; however, A2B3 treatment occurs real interaction between oleoresin concentration and Tween 20 , so that it is obtained the smallest particle size of $44,95 \mathrm{~nm}$. The result is similar to the previous research or study in which the manufacturing of nanoemulsion is influenced by emulsification energy and type of surfactant [8].

Figure 4 showed that the kind of surfactant influenced particle size. Especially for surfactant Tween 80, which has size above $100 \mathrm{~nm}, 117.9 \mathrm{~nm}$ of A1B1, and $128.2 \mathrm{~nm}$ of A2B1 produced on proper condition. While the combination of surfactant Tween 80 and Twen 20 with a ratio of $1: 1$ produced nano-sized particles below $100 \mathrm{~nm}$. This result is similar to what Sapei et al. done in their research in 2017; the surfactant mixtures are useful for reducing the destabilization rate of oilin-water emulsions. Structurally, the emulsifier is an 
amphiphilic molecule whose have hydrophilic molecule and lipophilic groups. The solubility of emulsifiers in water follows the Hydrophile-Lyphophile Balance rating [29].

The Hydrophile-Lyphophile Balance (HLB) value of the emulsifier ranges from 1 to 20. HLB value between 1-10 is lipophilic while $10-20$ is hydrophilic. The emulsifier's hydrophilic part has a water-compatible group because it has a polar pole that can bond with water and water-soluble molecules. The lipophilic part has an oil-compatible group composed of hydrocarbons mixed with oil and insoluble in water [30].

Moreira et al. [22] stated that high surfactant concentration, high, stirring speed, and a certain emulsification temperature made the particle size of the emulsion smaller so that the emulsion stability was achieved [31].

2) Zeta Potential: Zeta potential is defined as the potential difference between the dispersion medium and the stationary layer of fluid attached to the particle. It explained the electrical potential at the inner surface, which measured using a potential zeta analyzer. It occurred due to an electric current on some surface area. The stability of the colloid could be predicted using zeta potential [19].

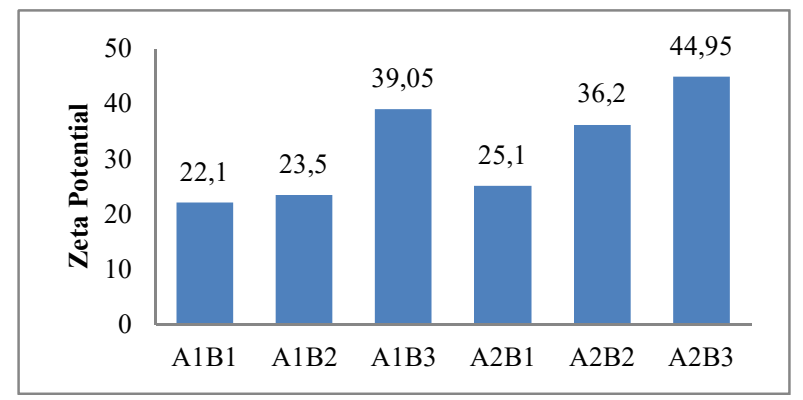

Where:

Fig. 6 Zeta potential nanoemulsion of andaliman

A1: Concentration Oleoresin 10\% A2: Concentration Oleoresin 20\%

B1: Tween $80 \quad$ B2: Tween 20:Tween $80=1: 1 \quad$ B3:Tween $20 \%$

Oleoresin concentration, type of surfactant and their interaction affect zeta potential. It means those parameters significantly affect the stability of the emulsion. Figure 5 showed that surfactant of Tween 80 , which prepared by treatment B1, with the same concentration of oleoresin, did not make the stable emulsion. It reflected by the zeta potential value of $-22.1 \mathrm{mV}$ and $-25.1 \mathrm{mV}$ on $\mathrm{A} 1 \mathrm{~B} 1$ and $\mathrm{A} 2 \mathrm{~B} 1$, respectively. This result is because the working surfactant on the inner surface cannot overcome the agglomeration. While the surfactant of Tween 20, which prepared by treatment B3 with higher oleoresin concentration, has higher zeta potential. It reflected by the zeta potential value of $-44.95 \mathrm{mV}$ and $39.05 \mathrm{mV}$ on A2B3 and A1B3, respectively.

The type of surfactant and its concentration must be suitable with emulsified material because it may cause an oilto-water interface tension to low. Thus, it can reduce the recoalescence process; Then, the stable emulsion could be produced as represented from the potential zeta size in figure 6 . It could prevent both absorption of particle interface and coagulation during the emulsification process.

Emulsion concentration of $20 \%$ and emulsifier Tween 20 (A2B3) showed a stable emulsion because the zeta value was the highest in this treatment (according to the emulsion stability index in figure 8 , the value is 100 ).

Tween 20 emitters in andaliman nanoemulsion adsorb more quickly to the droplet surface and suppress interface stress. The emulsifier adsorption rate is faster than the droplet fragmentation rate so that the droplet is completely coated with the emulsifier [32].

The surfactant mixture with an appropriate oil concentration can reduce the destabilization rate of oil emulsion in water because the appropriate HydrophileLyphophile Balance (HLB) is formed [33].

On the other hand, the zeta potential of mixed surfactant $80: 20(1: 1)$ with treatment B2 is around $-36.2 \mathrm{mV}$. It showed the droplet's stability, shown by previous research on $-30 \mathrm{mV}$ [21]. It showed that Tween 20 is more suitable for the andaliman nanoemulsion process than both Tween 80 and mixed Tween 80 and Tween 20. It can stabilize the emulsion and unify the different phases. Based on Jumanca et al., a range of $-30 \mathrm{mV}$ to $-40 \mathrm{mV}$ is typical moderate emulsion stability [34]. While the range of $-41 \mathrm{mV}$ to $-60 \mathrm{mV}$ is typical high emulsion stability.

It showed that the attractive force is increased with the decreasing of zeta potential, so both coagulation and flocculation will occur. On the other hand, the repulsive force is our research increased with the increasing of zeta potential, as stated by previous [7]. The emulsion can absorb the particle so that it can protect the surface of the surfactant. This caused a decrease of zeta potential [35], [36].

3) Poly Dispersity Index (PDI): Particle size distribution expressed as polydispersity index (PDI). If the value of PDI is small, it showed that dispersion is stable. If the value is 0 , it indicates monodisperse particles, whereas if 0.5 indicates the particle size distribution width. [37].

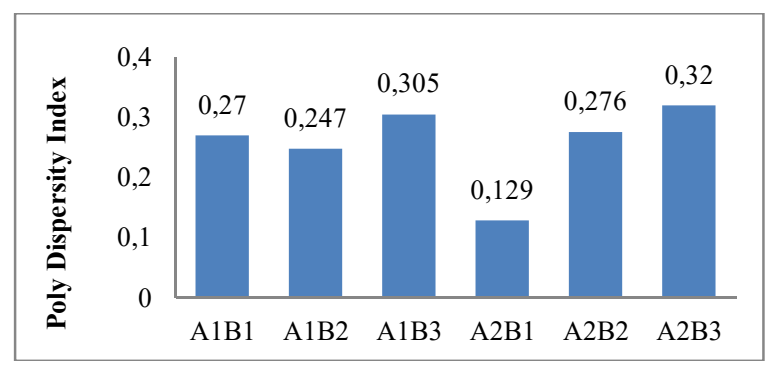

Fig. 7 Poli Dispersity Index Nanoemulsion of Andaliman

Figure 7 showed no significant difference in PDI on different parameters such as oleoresin concentration, type of surfactant, and interaction. According to the value of PDI categorized as a homogeneous mixture if it is less than 1 . The $10.8 \mathrm{~nm}$ quercetin nanoemulsion particles had a PDI of 0.349 [38]. The measurement of PDI obtained a range of 0.1290.320 , which stated nanoemulsion of andaliman as homogeneous dispersity.

4) Emulsion Stability Index: Emulsion stability index (ESI) is strongly influenced by the type of surfactant and oleoresin concentration on the manufacturing of andaliman nanoemulsion. ESI is a parameter that measured the stability of the emulsion physically [39]. Gracia added ESI could measure the emulsion ability by comparing homogenized and 
unhomogenized emulsion. The value of ESI showed on Figure 7[40].

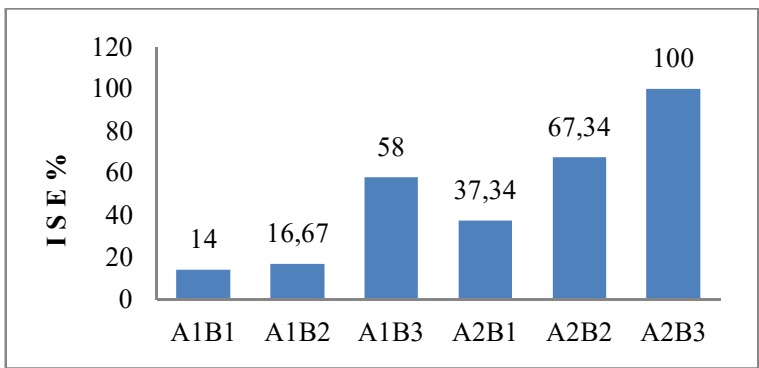

Fig. 8 Emulsion Stability Index (ESI) Nanoemulsion of Andaliman

Figure 8 showed $100 \%$ of ESI from the treatment of A2B3. It is a typical andaliman sample with $20 \mathrm{wt} \%$ of oleoresin concentration and surfactant of Tween 20. The number of interacting emulsions increases due to the nano-sized surface of extracted andaliman is bigger than before, thus stabilizing the emulsion. It is the same as the previous study [41]. The influence of surfactant type and composition on ESI values showed the change of globule on oil. Its result is similar to previous research, which stated the surface area increased with the decreasing of extracted size, absorbing more surfactants. Emulsion concentration of $20 \%$ and emulsifier Tween 20 (A2B3) showed a stable emulsion because the zeta value was the highest in this treatment (according to the emulsion stability index in Figure 7, the value is 100).

5) Viscosity of Emulsion: Viscosity is a type of parameter in the stability and efficiency of releasing active components. It is friction between adjacent fluid layers as it moves across each other [42]. All components such as water, oil and surfactant influenced the viscosity of formed nanoemulsion. Figure 9 showed that there is no significant difference in nanoemulsion viscosity due to different raw material and formulation on the manufacturing of nanoemulsion. The highest viscosity is A2B3 which consists of 20 wt.\% of oleoresin and surfactant of Tween 20. It is strongly affected by particle size. The particle size is decreased with the increase of surface area, so it absorbs more surfactant and produces stable and thick emulsion.

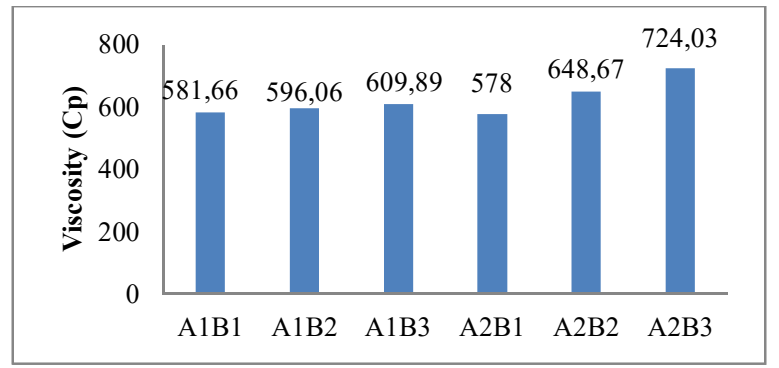

Fig. 9 Viscosity Nanoemulsion of Andaliman

Jusnita informed that viscosity is increased with the decreasing emulsion particle size. Different surfactants have different adsorption kinetics, affecting the merge of droplet because the formation of nano-sized particles causes the surface to absorb surfactants and prevent flocculation [35], [43].

\section{CONCLUSION}

Nanoemulsion which conducted using ultra turrax homogenizer with speed around $18000 \mathrm{rpm}$ using Tween 20 emulsifier and andaliman oleoresin concentration of $20 \%$ wt. With a long homogenization time of 15 minutes, it can produce $68.5 \mathrm{~nm}$ stable emulsion with zeta potential -44.95 $\mathrm{mV}$ and $100 \%$ emulsion stability with viscosity $724.03 \mathrm{cps}$.

\section{REFERENCES}

[1] Khairunnisyah AY. Pemanfatan andaliman (Zanthoxylum acanthopodium DC) sebagai tanaman penghasil minyak atsiri. $J$. Kultivasi, vol.17,(1), pp. 537-543, 2018.

[2] Rienoviar and Setyaningsih D. Studi senyawa aroma ekstrak andaliman (zanthoxylum acanthopodium) dari beberapa pelarut menggunakan Gas Chromatography-Mass Spectra (GC-MS). Warta IHP, vol.35, (2), pp. 85-90, 2018.

[3] Natasutedja AO., Lumbantobing E., Josephine E., Carol L., Junaedi DI., Normasiwi S., Naro Putra AB. Botanical Aspects, Phytochemicals and Health Benefits of Andaliman (Zanthoxylum acanthopodium DC). Indonesian J of Life Science, vol. 1, No. 2, 2019.

[4] Wijaya CH., Napitupulu FI., Karnady V., Indariani S. A review of the bioactivity and flavor properties of the exotic spice "andaliman" (Zanthoxylum acanthopodium DC.). Food Reviews International, vol. 35, (1), pp. 1-19, 2019.

[5] Djati MS., Christina YI. Rempah-rempah Indonesian traditional food flavor toward modern functional food and herbal medicine. Functional Foods in Health \& Disease, vol. 9, (4), 2019.

[6] Ashlee DB., Hugh DCS., Robert OWIII. Disperse Systems: Suspensions. Essential Pharmaceutics, pp. 91-110, 2019.

[7] Amalia A, Jufri M, and Anwar E. Preparasi dan karakerisasi sediaan solid lipid nanoparticle (sln) gliklazid. Jurnal Ilmu Kefarmasian Indonesia, vol.13, (1), pp.108-114, 2015.

[8] Sheth T., Seshadri S., Prileszky T., Helgeson ME. Multiple nanoemulsions. Nature Reviews Materials, vol. 5, pp. 214-228, 2020.

[9] Arshad H., Ali TM., Hasnain A. Native and modified Sorghum starches as wall materials in microencapsulation of nutmeg oleoresin. International J of Biological Macromolecules, vol. 114, pp. 700-709, 2018.

[10] Delfiya DSA, K Thangavel, N Natarajan, R Kasthuri and R Kailapan. Microencapsulation of turmeric oleoresin by spray drying and in vitro release of microcapsules. J of Food Process Eng., vol. 38, pp. 3748, 2015.

[11] Suganya V, Anuradha V, Ali MS, Sangeetha P and Bhuvana P. Microencapsulation and characterisation of astaxanthin prepared using different agent. Research J of Chem., vol.7, (12), pp. 1-10, 2017.

[12] Zhu Z., Wen Y., Yi J., Cao Y., Lio F., McClements DJ., Comparison of natural and synthetic surfactants at forming and stabilising nanoemulsions: Tea saponin, Quillaja saponin and Tween 80. Journal of Colloid and Interface Science, vol 536, pp 80-87, 2019.

[13] Amarachi CS, Attama AA, KenechukwuF. 2014. Nanoemulsions, Advances in Formulation, Characterisation and Applications in Drug Delivery. p. 78-126. http://dx.doi.org/10.5772/15371

[14] Rosenberg Mdan Sheu TY. Microencapsulation of volatiles by spraydrying in whey protein-based wall systems. International Dairy J, Vol 6 (3), p. 273-284,1996.

[15] Zuidam NJ and Victor N. Encapsulation Technologies for active food ingredient and food processing. New York: Springer. 2010. DOI 10.1007/978-1-4419-1008-0.

[16] Hui YH. 1992. Encyclopedia of Food Science and Technology. Volume II. Canada: John Willey and Sons Inc.

[17] Assadipour E dan Jafari SM. Advances in spray-drying encapsulation of food bioactive ingredients: from microcapsules to nanocapsules. Annual Review of Food Science and Technology, vol. 10, pp. 103-131, 2019.

[18] Ralla T., Salminen H., Tuosto J., Weiss J. Formation and stability of emulsions stabilised by Yucca saponin extract. International Journal of Food Science \& Technology, vol. 53, (6), 2017.

[19] Cacua K., Ordonez F., Zapata C., Herrera B., Pabon E., BuitragoSierra R. Surfactant concentration and $\mathrm{pH}$ effects on the zeta potential values of alumina nanofluids to inspect stability. Colloids and Surface A: Physicochemical and Engineering Aspects, vol. 583, pp. 123960, 2019. 
[20] Connor DO, Calautit J, and Hughes BR. Effect of rotation speed of rotary thermal wheel on ventilation supply rates of wind tower system. Energy Procedia., vol.75, pp. 1705-1710, 2015.

[21] Artiga-Artigas M., Lanjari-Perez Y., Martin-Belloso O. Curcuminloaded nanoemulsions stability as affected by the nature and concentration of surfactant. Food Chemistry, vol. 266, pp. 466-474, 2018.

[22] Moreira B, Goularte PG, Morais MG, Costa JAV. Preparation of betacarotene nanoemulsion and evaluation of stability at a long storage period Juliana. Food Sci. Technol, Campinas, 39(3): 599-604, 2019.

[23] Prince M V, Thangavel K, Meda V, Visvanathan R, and Ananthakrishnan D. Effect of carrier blend proportion and flavor load on physical characteristics of nutmeg (Myristica frangrans Houtt.) oleoresin microencapsulated by spray drying. International Food Research. J., vol. 21, (5), pp. 2039-2044, 2014.

[24] Dammak I., do Amaral Sobral PJ. Effect of different biopolymers on the stability of hesperidin-encapsulating $\mathrm{O} / \mathrm{W}$ emulsions. Journal of Food Engineering, vol. 237, pp. 33-43, 2018.

[25] Setyawati DM, Mardliyati E, Rahman S and Wijaya AF. Spray drying of mangosteen (Garcinia mangostana L.) juice and analysis of antioxidant activity and total phenolic content. IOP Conf. Series: Materials Science and Engineering 796. 2020. Doi:10.1088/1757899X/796/1/012046.

[26] Tsai FH., Kitamura Y., Kokawa M. Effect of gum Arabic-modified alginate on physicochemical properties, release kinetics, and storage stability of liquid-core hydrogel beads. Carbohydrate Polymers, vol. 174, pp. 1069-1077, 2017.

[27] Hermanto RF, Khasanah LU, Kawiji, Atmaka W, Manuhara GJ, and Utami R. Physical characteristics of cinnamon oil microcapsule. Joint Conference on Chemistry. vol.107, pp. 1-9, 2016.

[28] Mariod A. Chemical Properties of Gum Arabic Abdalbasit.p.67=73. https://doi.org/10.1016/B978-0-12-812002-6.00006-3

[29] Chemmunique 1980. The HLB System a Time Saving Guide to Emulsifier Selection. Wilmington, Delaware 19897: ICI Americas Inc

[30] Joshi M, Adhikari B, Aldred P, Panozzo JF, Kasapis S, Barrow CJ. 2012. Interfacial and emulsifying properties of lentil protein isolate. Food Chemistry, 134: 1343-1353

[31] Bernardi, DS, Pereira TA, Maciel NR, Bortoloto J, Vieira GS, Oliveira, GC. Formation and stability of oil-in-water nanoemulsions containing rice bran oil: in vitro and in vivo assessments. Journal of Nanobiotechnology, 9(44), 1-9, 2011.https://doi.org/ 10.1186/14773155-9-44.

[32] Clements DJ, Gumus CE. Natural Emulsifiers - Biosurfactants, Phospholipids, Biopolymers, and Colloidal Particles: Molecular and
Physicochemical Basis of Functional Performance. $\boldsymbol{J}$ Advances in Colloid and Interface Sci., pp. 1-100, 2016.

[33] Sapei L, Sandy IGYH, Suputra IMKD and Ray M. 2017. The effect of different concentrations of tween-20 combined with rice husk silica on the stability of o/w emulsion: A kinetic study. IOP Conf. Series: Materials Science and Engineering 273: 012023. Doi:10.1088/1757899X/273/1/012023.

[34] Jumanca D., Matichescu A., Galuscan A. An experimental method of producing hydroxyapatite. Rev. Chim, vol. 6, (6), 2018.

[35] Yu X., Xin X., Xu B., Wu T., Wang P. Synthesis and characterisation of alumina sol-modified polyacrylate emulsion. Advanced Graphic Communications, Packaging Technology and Materials, pp. 861-868, 2016.

[36] Saeedi M, Rafati MR, Semnani KM, Rostam AY, and Kelidari HR. Evaluation of effect of Tween 80 on characteristics of tadalafil $0.1 \%$ suspension. Pharm. and Biomedical Research., vol. 1, (2), pp. 35-43, 2015.

[37] Prasetyo YA, Husni P, Mita SR. Long-Circulating Nanopartikel menggunakan polimer PLGA (PolyLactic-co-Glicolyc Acid) dan Poloxamer, Farmaka, vol.15, (1), pp. 237-247, 2018.

[38] Atun S., Arianingrum R., Cahyaningsih L., Pratiwi FA., Kusumaningrum R., Khairuddean M. Formulation and characterisation of quercitrin nanoemulsion isolated from Dendropthoe falcate and its antioxidant activity test. Rasayan J. Chem, vol. 13 (3), pp. 1347-1356, 2020.

[39] Clements DJ, Gumus CE. Natural Emulsifiers - Biosurfactants, Phospholipids, Biopolymers, and Colloidal Particles: Molecular and Physicochemical Basis of Functional Performance. J Advances in Colloid and Interface Sci., pp. 1-100, 2016.

[40] Garcia LC, RV Tonona, and MD Hubingera. Effect of oil in emulsion and homogenisation pressure on the microencapsulation of basil oil, 2014.

[41] Kohli HP., Gupta S., Chakraborty M. Stability, and performance study of emulsion nanofluid membrane: A combined approach of adsorption and extraction of Ethylparaben. Colloids and Surfaces A: Physicochemical and Engineering Aspects, vol. 579, pp. 123675, 2019.

[42] Juniatik M, Hidayati K, Wulandari FP, Pangestuti N, Munawaroh N, Martien R, Utami S. Formulation of nanoemulsion mouthwash combination of lemongrass oil (Cymbopogon citratus) and kaffir lime oil (Citrus hystrix) AGAINST Candida albicans ATCC 10231. Trad. Med. J., Vol. 22(1), p. 7-15, 2017.

[43] Jusnita N, Haditjatoko L, Yusron M, Noor E. Production of Nanocurcumin from Curcuma Xanthorriza Roxb. By Homogenisation. J of Biology, Agric and Healthcare, vol. 4, (16), pp.79-83, 2014. 